\title{
DEVELOPING DIGITAL PLATFORM OF THE ASKIN APPLICATION USING HOUSE OF QUALITY
}

\author{
Yudha Heryawan Asnawi ${ }^{* 1}$, Naura Rahmalia*), Suhendi*) \\ ${ }^{*}$ School of Business, IPB University \\ Jl. Pajajaran, Bogor 16151, Indonesia
}

\begin{abstract}
Healthcare is the need of many people to fulfill their lifestyles. The desire to achieve maximum appearance encourages everyone to the healthcare of skin. The relatively high cost and the low number of aesthetic doctors in certain areas have led some people to do facial treatments independently using skincare products. Askin's business idea in the form of a facial care application is one of the solutions to help users with facial skincare. This research aims to analyze the problem factors of skincare users in carrying out facial skincare, analyze the right solution, and design a Minimum Viable Product that suits the Askin application. This research was conducted from December 2020 to January 2021 using the House of Quality research method to identify the best features. This research also used female research respondents aged 19-34 years using skincare products and domiciled in the City of Bukit Tinggi as a sample of this study. The results of this research contained six problems from skincare users, which is not knowing the type/condition of the skin in detail, not knowing the right skin care product to use, experiencing an incompatibility when using skincare products, difficulty obtaining skincare products, having no place to ask and consult, and not using skin care regularly. In conclusion, the Askin Application has ten application features formulated based on consumer needs and desires. These features are implemented in the minimum viable product of the Askin application.
\end{abstract}

Keywords: business development, digital platform, facial care, house of quality

\begin{abstract}
Abstrak: Kesehatan merupakan kebutuhan banyak orang untuk memenuhi gaya hidupnya. Keinginan untuk tampil maksimal mendorong setiap orang untuk menjaga kesehatan kulit. Biaya yang relatif mahal dan minimnya jumlah dokter kecantikan di daerah tertentu membuat sebagian orang melakukan perawatan wajah secara mandiri menggunakan produk perawatan kulit. Ide bisnis Askin berupa aplikasi perawatan wajah menjadi salah satu solusi untuk membantu pengguna dalam perawatan kulit wajah. Penelitian ini bertujuan untuk menganalisis faktor permasalahan pengguna skincare dalam melakukan perawatan wajah, menganalisis solusi yang tepat, dan merancang Minimum Viable Product yang sesuai dengan aplikasi Askin. Penelitian ini dilakukan pada bulan Desember 2020 hingga Januari 2021 dengan menggunakan metode penelitian House of Quality untuk mengidentifikasi fitur-fitur terbaik. Penelitian ini juga menggunakan responden penelitian wanita berusia 19-34 tahun yang menggunakan produk perawatan kulit dan berdomisili di Kota Bukit Tinggi sebagai sampel penelitian ini. Hasil dari penelitian ini terdapat enam permasalahan dari pengguna skincare, yaitu tidak mengetahui jenis/kondisi kulit secara detail, tidak mengetahui produk perawatan kulit yang tepat untuk digunakan, mengalami ketidaksesuaian saat menggunakan produk skincare, kesulitan mendapatkan produk skincare, memiliki tidak ada tempat untuk bertanya dan berkonsultasi, dan tidak menggunakan perawatan kulit secara teratur. Kesimpulannya, Aplikasi Askin memiliki sepuluh fitur aplikasi yang diformulasikan berdasarkan kebutuhan dan keinginan konsumen. Fitur-fitur ini diimplementasikan dalam produk minimum yang layak dari aplikasi Askin.
\end{abstract}

Kata kunci: pengembangan bisnis, platform digital, perawatan wajah, rumah kualitas

\footnotetext{
${ }^{1}$ Corresponding author:

Email: yudhaherryasnawi@yahoo.com
} 


\section{INTRODUCTION}

Healthcare Business is one of the businesses that are currently very important for various communities. The existence of this business can affect people's lifestyles. However, currently, healthcare is very difficult to reach by the public because of the accessibility factor, which requires a lot of time to access. In addition, this business is very dependent on the convenience preferences of its customers, so that customers sometimes have to look for other healthcare that suits their preferences. One of the most sought-after healthcare is skin health.

Skin is one of the organs in the body that has the function of wrapping meat and protecting the body's internal organs. This important skin function requires everyone to maintain and take care of the skin in order to be able to function properly; one step that can be done is to take care of the skin (Sugiarti, 2017). According to Andriana (2014), a person's beauty and health are reflected by their skin condition, so it is very important to take care of the skin, especially facial skin, to overcome problems experienced on facial skin. Markplus, Inc and Zap Clinic (2018) conducted a survey of 17,889 women in Indonesia and found that $58.7 \%$ of women had acne or blackhead problems, 55.7\% had problems with spots or acne scars, $36.4 \%$ had dull skin problems, $38.5 \%$ had problems with large pores, and $29.1 \%$ had problems with excess oil content. These data illustrate that a fairly high percentage of women experience various types of facial skin problems. In addition, other survey results from Markplus, Inc and Zap Clinic (2018) state that $76.8 \%$ of women in Indonesia feel that health, especially facial health, is the most valuable thing to have.

In doing facial care, people tend to go to a beauty doctor or beauty clinic. In facial treatment to a beauty doctor or beauty clinic, there are problems experienced by some people, such as relatively expensive consultation and treatment costs and the lack of doctors or beauty clinics in certain areas (Sirapanji, 2014). This condition is one of the reasons why people do facial care independently using skincare products sold in the market as a solution to solve problems on their facial skin. Facial care with skincare products sold in the market requires users to be more careful in choosing facial skin care products to use. According to Alya (2018), the use of facial skincare products that are not in accordance with the classification of skin types will cause damage to the skin. In addition, consistency is also an important factor in facial skincare. With the encouragement for everyone to care for facial skin, to overcome facial skin problems they experience, the skincare industry in Indonesia continues to grow. Data from Statista (2020) states that the largest market for the Indonesian cosmetic industry is the skincare segment, with an estimated market volume of USD 1,673 million in 2019. This data also proves the high interest of the Indonesian people to do skincare, especially facial skin.

Based on the facts and problems above, the author wants to help everyone carry out facial skincare so that they can solve their facial skin problems and have healthy facial skin. The author wants to create an innovative application-based digital platform that provides various integrated solutions in one container. The digital platform was chosen as a medium of connection because of the increasing access to the internet. In addition, the condition of the Covid-19 pandemic is currently happening in Indonesia and demands to work and carry out activities at home, causing more and more people to use the internet as a medium of communication. Based on data from the Indonesian Internet Service Users Association (2020), in the second quarter of 2020, when the Covid-19 pandemic has entered Indonesia, Indonesia's number of internet users is $73.7 \%$ of the population or the equivalent of 196.7 million users. This fact can be an opportunity to create a business in the form of a digital platform. Based on the facts, problems, and opportunities, create an application-based digital platform that will help every skincare user carry out facial skincare called Askin. Askin is developed by adapting the features of digital healthcare application. In order to develop Askin's business idea into a comprehensive idea, the author needs further research on the feedback process for potential customers.

\section{METHODS}

This research was conducted in the City of Bukittinggi from December 2020 - January 2021. The types of data and information used in this research came from two data sources: primary data obtained from surveys and interviews with respondents and secondary data obtained from various kinds of literature, such as official websites, journals, and scientific publications. The primary data collection technique that the writer uses is non-probability sampling in the form of purposive sampling. For the initial stage of technical 
saturation, the number of samples will be determined until the respondent's answer is at the saturation point (with the same answer) and will be multiplied by two to confirm and strengthen the results. For the next stage of the house of quality, the technique of calculating the number of samples uses the Slovin formula, and the results of the number of samples use 100 samples. In the next stage, the analysis of a sample was carried out, and 30 potential respondents were determined according to the criteria for rearranging the features of the Askin application. According to Agung (2006) in Alwi (2012), the minimum number of research samples is 30 respondents. So, taking 30 potential respondents for the solution test stage has met the minimum limit of respondents. To achieve the research objectives, the author will carry out the stages of research with the flow chart in Figure 1.

The data analysis of this research is using the house of the quality method. According to Wijaya (2011), the QFD method is a method that prioritizes a systematic approach by prioritizing consumer needs and translating them accurately into product development plans so that they can provide quality products or services to consumers. The house of quality can maximize resources and minimize costs by ensuring that the product is created precisely that focuses on the problem that is prioritized on the needs of several needs. Hauser (1988) was explained the process of House of Quality started with Customer Requirement, Planning Matrix, Technical Response, Relationship Matrix, Technical Correlation, and then Target Matrix. The study of Kurniasih (2013) showed consumers' needs and desires for products from using the house of quality. Purwati et al. (2017), in the study of Total quality service analysis, shows 29 attributes of customer needs and wants and 31 technical requirements formulated to meet customer wants and expectations. Shrivastava (2013) mention the major reasons to employ House of Quality such as Complexity of product development; Extended development time caused by excessive redesign, problem-solving, or firefighting; Customers are complaining or aren't satisfied with the product or service; Lack of efficiency and effective product/ process development teamwork; Market share has been consistently declining; Lack of structure to the allocation of product development resources.

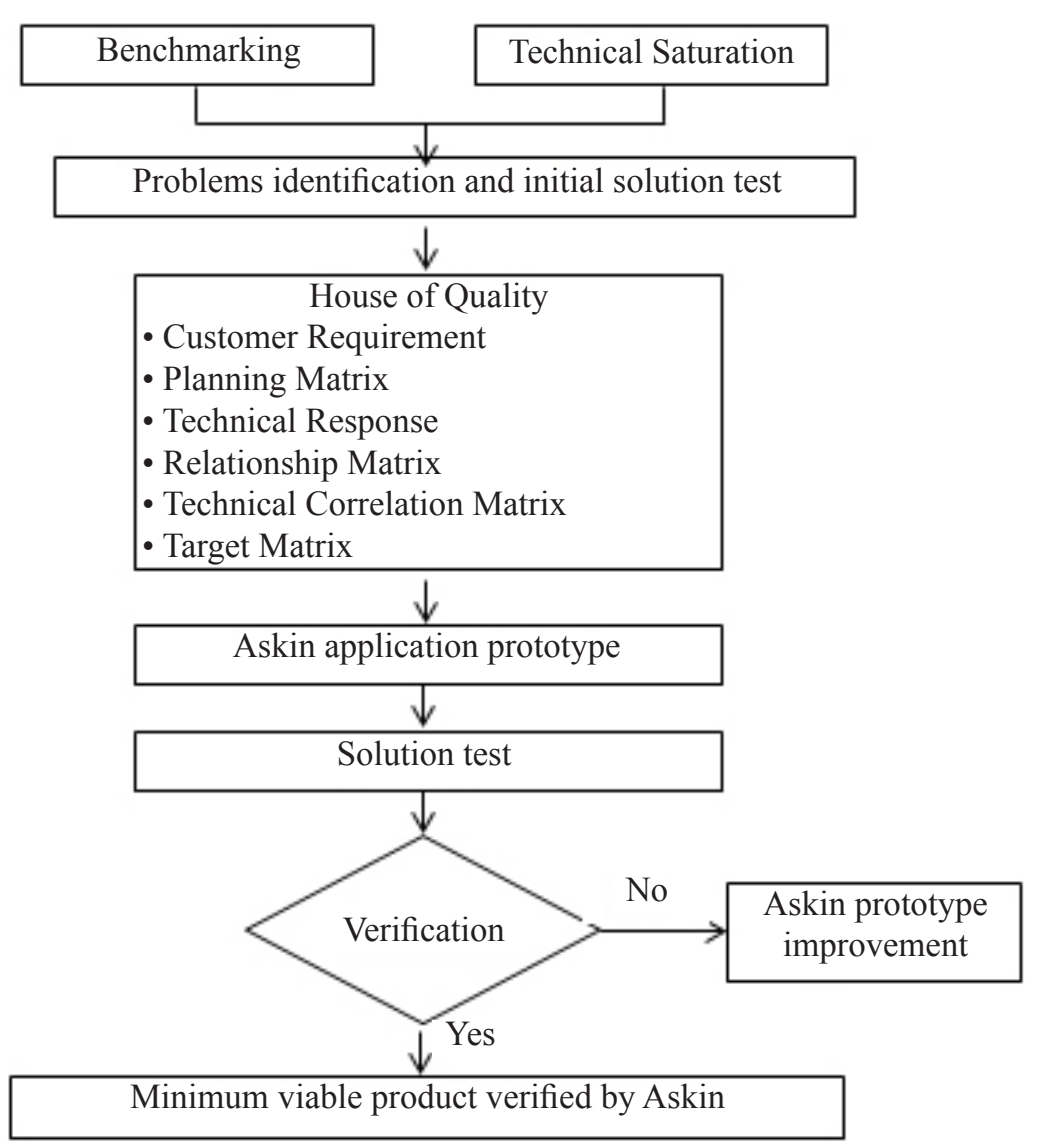

Figure 1. Research framework 
In conducting this research, the authors conducted a validity test to determine the level of accuracy in using one of the variables in the questionnaire and a reliability test to obtain consistent data from time to time. There are three data that are tested for validity: data on skincare user problems, data on attributes of needs and respondents' desires, as well as feature attribute data that respondents need and want. As a result, it was found that each variable from the research questionnaire was valid and feasible to use.

\section{RESULTS}

\section{Benchmarking}

The first stage of this research is to conduct benchmarking against similar companies from Askin, which are used as benchmarks or references in order to improve performance and productivity. In this research, the authors used the Halodoc and Troveskin companies as benchmark companies with the indicators: vision, services offered, problems resolved, geographic reach, and price. There are several points that Askin can adapt: first, Askin will be designed in the form of an application that is used online and is not limited. Second, Askin Services will be available for free, except for consulting services that use the services of a dermatologist during the process. Third, the features of Askin are not only limited to facial skin analysis and consultation but will be supported by several other additional features that will maximize user satisfaction.

\section{Technical Saturation}

The results of the technical saturation stage are a list of problems experienced by respondents obtained from the questionnaire. After distributing the questionnaire, it was found that the saturation point was related to problems in the use of skincare products for six respondents. However, the authors distributed a questionnaire twice the number of saturated point respondents of 12 respondents to ensure this. The problems experienced by respondents in using skincare for facial skincare are not knowing the type/condition of the skin in detail (P1), not knowing the right skin care product to use (P2), experiencing a mismatch when using skincare products (P3), difficulties in obtaining skincare products ( $\mathrm{P} 4)$, do not have a place to ask and consult (P5), and do not use skincare regularly (P6).

\section{Identification of Problems and Initial Solutions}

At this stage, the solution formulation of skincare user problems is carried out based on the results of benchmarking and technical saturation that has been done previously. The form of the initial solution that the author designed was a list of features of the Askin application that was able to solve problems and meet the needs and desires of the respondents. The following are the features of the Askin application, along with the problems that are resolved by each feature.

Table 1 Early solutions features of Askin application

\begin{tabular}{lc}
\hline Feature & Problem \\
\hline Face Scan & P1 \\
Consultation with a dermatologist & P5, P2, P3, P4, P1 \\
Daily tips skincare & P2 \\
Skin diary & P6 \\
Facial health targets & P6 \\
Reminder skincare routine & P6 \\
Rewards for achieving targets & P6 \\
Skincare community & P5 \\
Article content related to skincare & P2 \\
Video content related to skincare & P2 \\
\hline
\end{tabular}

The results of this study indicate that the initial solution required by this application is dominated by consultation with a dermatologist. This condition shows that the development of this application requires digital application-based telemedicine. Research conducted by Loomba et al. (2019) shows that telemedicine is able to become a service provider that can reach customer areas to remote locations to evaluate, diagnose, and treat patients. Current research provides evidence of the advantages of digital telemedicine are able to monitor remote patients, remote consultation, improved health care administration and management, integration of health data systems, and patient movement tracking (Acharibasam and Wynn, 2018). In Addition, there are various categories to develop a digital platform based on this problem that was identified. Anthony (2020) mentioned telehealth help patients receive care from physicians synchronously or asynchronously. Synchronization provides real-time digital meetings involving one-on-one meetings via webcam-enabled teleconferencing. Synchronous sessions are mostly used when the discussion is required, such as during new consultation consultations, counseling, evaluations, and follow-up examinations. Synchronization provides real-time digital meetings involving one-onone meetings via webcam-enabled teleconferencing. 
Synchronous sessions are mostly used when the discussion is required, such as during new consultation consultations, counseling, evaluations, and follow-up examinations (Rao et al. 2020). While asynchronous can include platforms such as online consultation clinics, where certified medical experts are available 24 hours/day to conduct primary examinations via remote consultation (Song et al. 2020). Completely, Anthony (2020) was categorized digital care on his study may include:

I. Telecare which is similar to synchronous employed via online consultations using videoconference or telephone for patients who ask for advice regarding health or report symptoms (Vidal-Alaball et al. 2020).

II. Sensor's devices such as Global Positioning System (GPS) trackers in remote applications notify users to avoid potentially high-level COVID-19 locations (Kapoor et al. 2020; Torous et al. 2020).

III.Kaminski et al. (2020) and Vidal-Alaball et al. (2020) was mentioned Virtual agents (Chatbots) for Frequently Asked Questions (FAQs), recommendations, and connecting quarantined patients to available physicians WHO recently deployed a chatbot using the WhatsApp program to provide the latest information and recommendations on the current state of COVID-19. Chatbot interacts with users via audio conversation or textual methods to provide health information (Okereafor et al. 2020).
IV. New innovations in augmented and virtual reality platforms can be employed but are not easily accessible or scalable (Tourous et al. 2020).

\section{House of Quality}

Based on the House of Quality method, Askin will develop a digital platform with ten features designed based on the needs and desires of consumers. Each of its features is implemented in the development and design of Askin's Minimum Viable Product. The House of Quality from Askin can be seen in Figure 2. The priority order of features that will be developed by Askin starts from the consultation feature with dermatologists, followed by facial scan features, skin diaries, daily skincare tips, skincare usage reminders, skincare user communities, article content, video content, skin health targets, and achievement rewards. Based on the survey results to respondents regarding the themes and colors of the Askin application, the application will use a light theme and pastel colors for brightness display. Askin application as a healthcare platform must-have feature's ability in information platforms, the data collection technology, market intermediaries, services for remote and on-demand healthcare, augmented and virtual reality provider, blockchain-based PHR, cloud service providers, and intelligent Data analysis for the healthcare providers (Hermes et al. 2020).

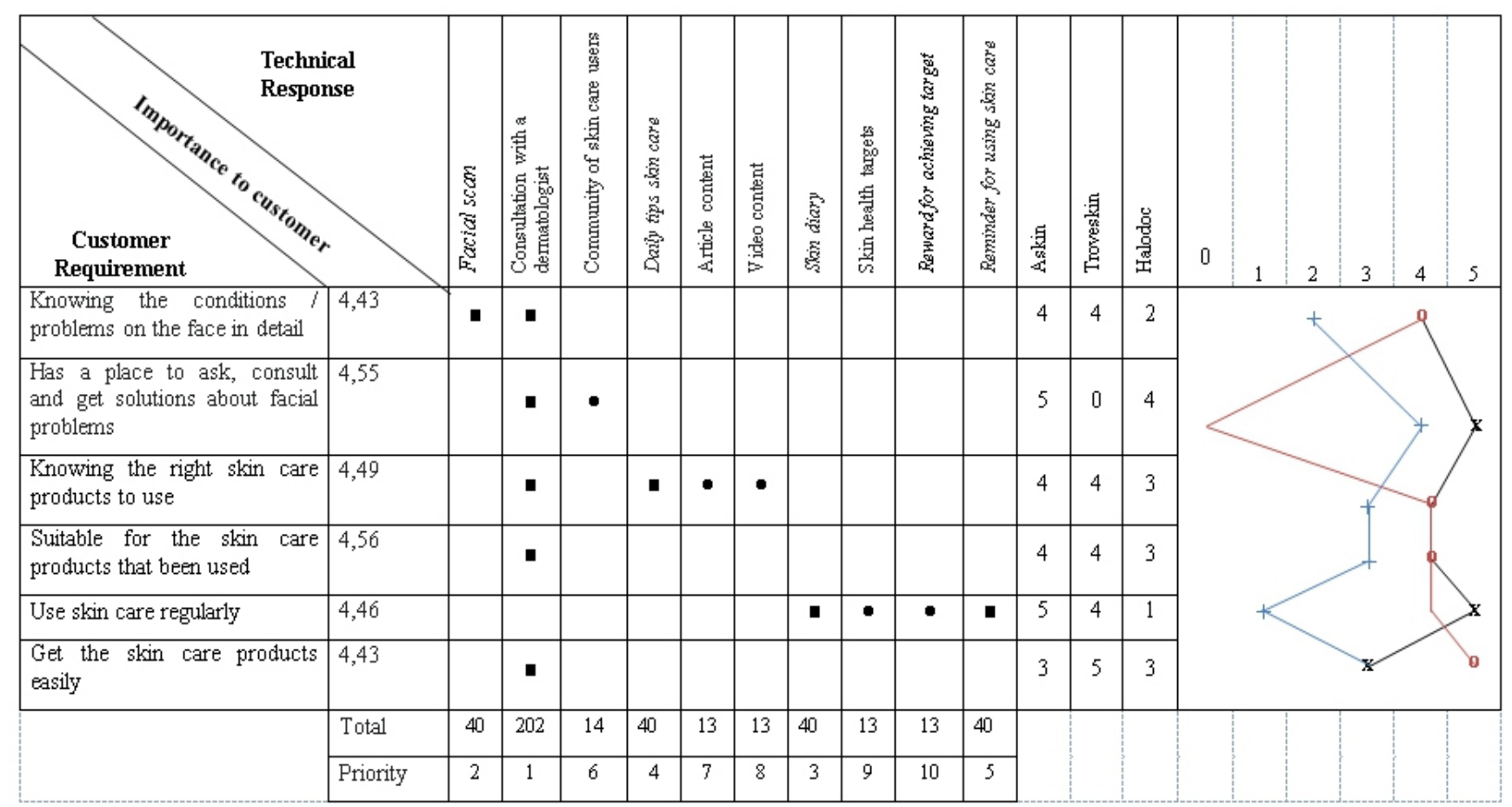

Figure. 2 House of quality Askin 


\section{Prototype}

This prototype is the result of the House of Quality and is supported by the results of benchmarking and technical saturation carried out in the early stages of the research. The prototype from Askin can be accessed at ipb.link/prototypeskin and can be seen in Figure 3.

\section{Solution Test}

The solution test stage was carried out on 30 potential respondents who had an interest in using the Askin application. The solution test stage accommodates responses and suggestions from respondents whose results will be used as the basis for improving the Askin prototype, so it can meet the respondent's needs and desires. Responses from respondents were 26 positive responses, and there were four suggestions for developing and improving the prototype: adding a doctor's portfolio to the consultation feature, providing a search feature and a consultation price filter, adding a testimonial feature, and providing a dark theme option.
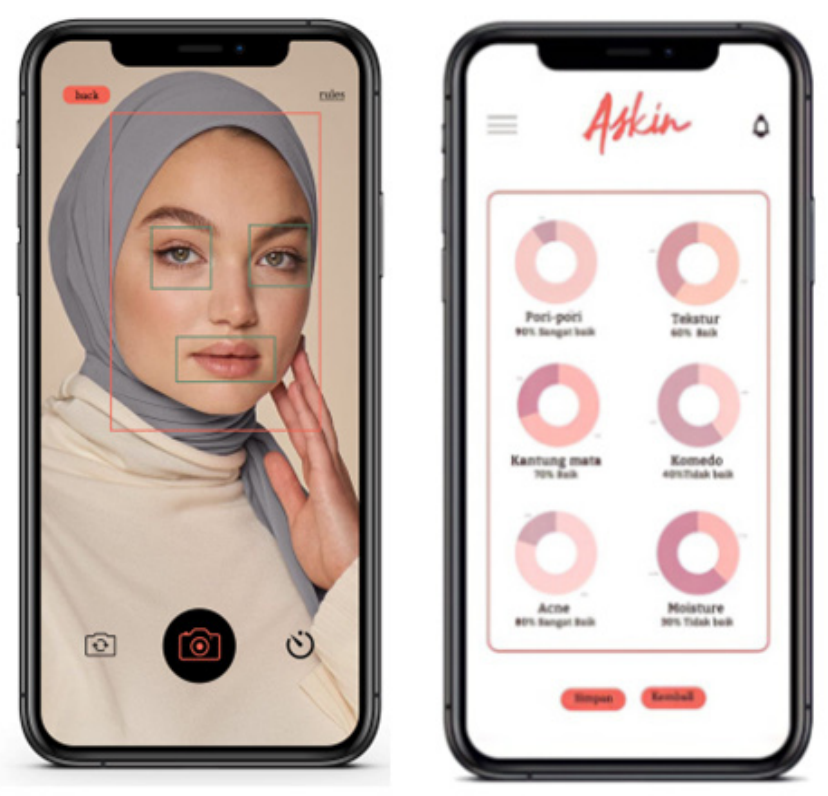

Figure 3. Prototype Askin
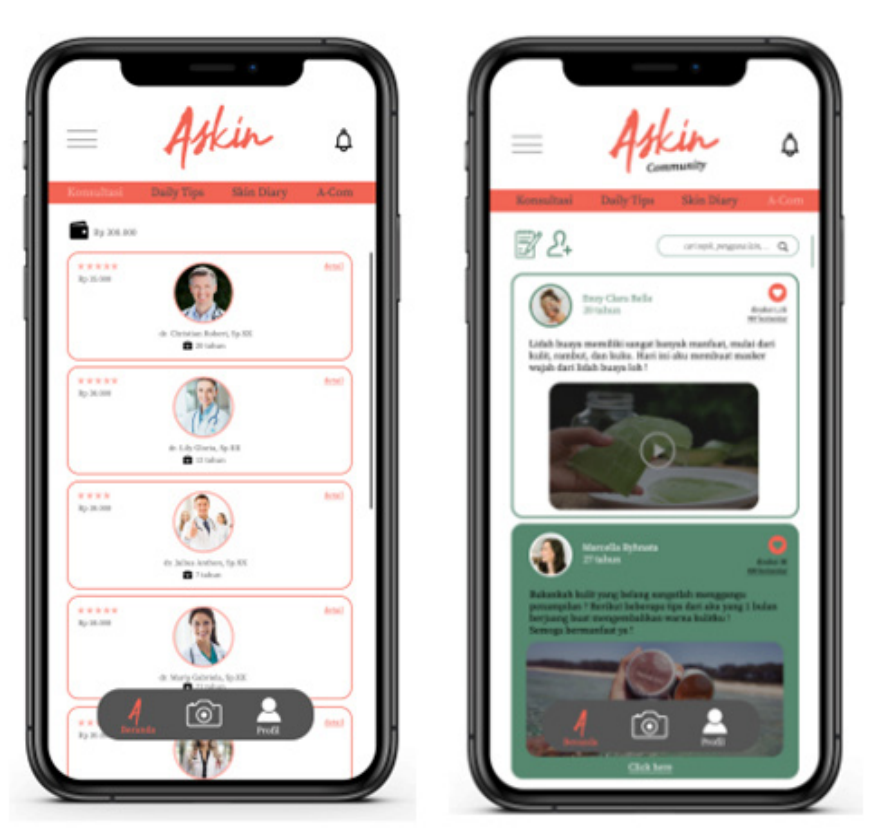

The results of the improvement of the Askin prototype resulted in the Askin Minimum Viable Product designed using the Marvel app program so the Askin application could be used. Minimum Viable Product Askin can be accessed at ipb.link/mvpaskin and prototype improvements can be seen in the following Figure 4.

\section{Managerial Implications}

The development of the skin application digital platform is carried out by identifying problems that occur in the condition of customers who use facial care services. Based on the problems that have been identified, it shows that customers need services that are easily accessible and affordable price ease of adapting from telehealth services that are currently developing. Digital platform development can be done by providing synchronous and asynchronous services. Synchronous and asynchronous services based on solution testing show that the features offered are acceptable to platform users. These conditions indicate their suitability between features priority based on the House of quality analysis and the desire and the need can be easily adopted by users of digital services. 

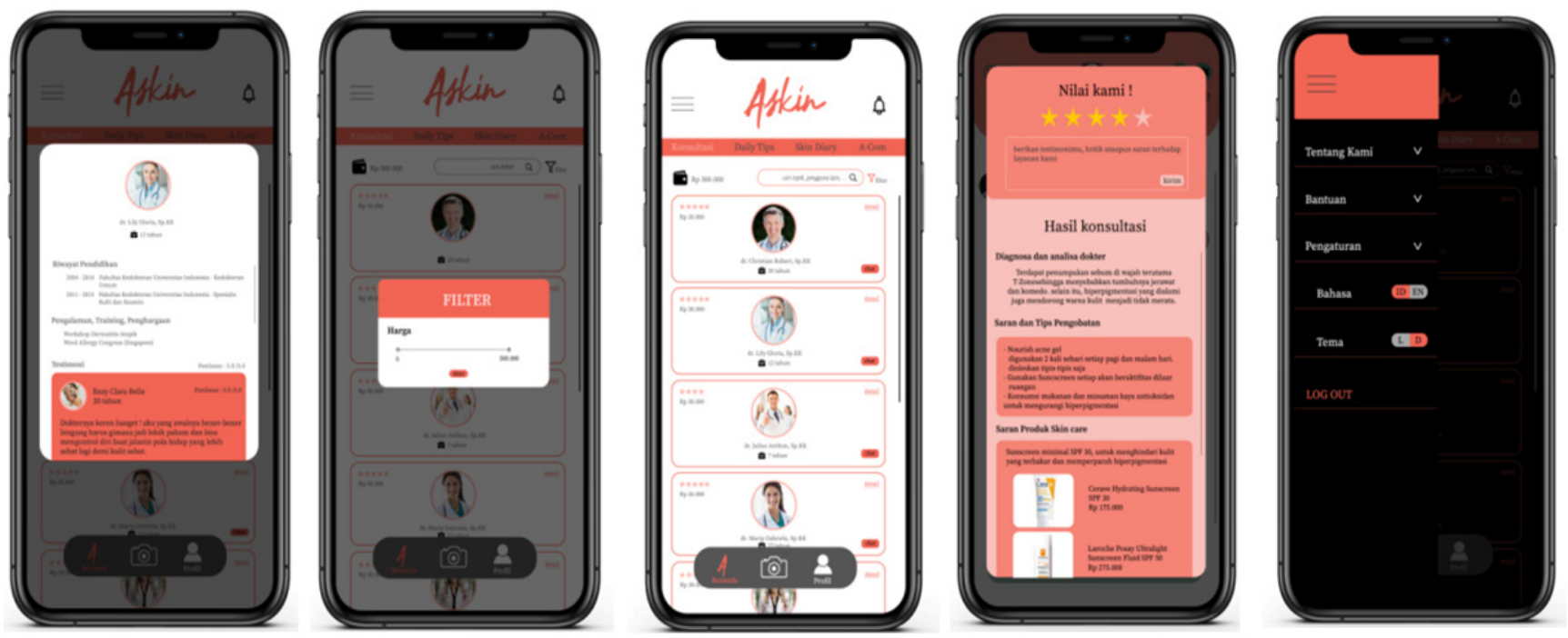

Figure 4. Minimum viable product Askin

\section{CONCLUSIONS AND RECOMMENDATIONS}

\section{Conclusions}

Facial skincare users encounter six main problems: not knowing the skin type/condition in detail, not knowing the right skincare product to use, experiencing an incompatibility when using skincare products, difficulty obtaining skincare products, having no place to ask/consult, and do not use skincare regularly. To overcome this problem, there is one solution, which is Askin application. Askin is a digital innovation that helps skincare users overcome problems that users face in doing facial skincare. Askin application is built using benchmarking, technical saturation, and the house of quality. Through these three methods, ten features are obtained based on the needs and desires of consumers, with the main feature to consult with a dermatologist. The features of Askin are interpreted in a Minimum Viable Product that has gone through the verification stage from potential respondents. The Askin application's Minimum Viable Product color theme is using pastel colors, which are the color choices of $90 \%$ of research respondents.

\section{Recommendations}

This study uses the House of Quality method, which is the first stage of Quality Function Deployment. The results of this study are the Minimum Viable Product from the Askin application, which can later be used for further research in solving consumer problems. Due to the limitations in completing all stages of Quality
Function Deployment, suggestions for further research can proceed to the next Quality Function Deployment stage. Namely the Part Deployment stage, which makes metrics to identify critical technical factors of Askin development, Process Planning to identify the digital platform creation process, and Process Control that elaborates the actions that need to be taken to improve the digital platform.

\section{REFERENCES}

Acharibasam JW, Wynn R. 2018. Telemental health in lowand middle-income countries: A systematic review. International Journal of Telemedicine and Applications 2018:1-10. https://doi. org/10.1155/2018/9602821.

Alwi I. 2012. Kriteria empirik dalam menentukan ukuran sampel pada pengujian hipotesis statistika dan analisis butir. Jurnal Formatif 2(2):140-148. https://doi.org/10.30998/formatif.v2i2.95.

Alya PD. 2018. Perancangan informasi perawatan kulit wajah dengan rempah-rempah melalui media buku ilustrasi [skripsi]. Bandung: Universitas Komputer Indonesia.

Andriana R. 2014. Minat konsumen terhadap perawatan kulit wajah dengan metode mikrodermabrasi di viota skin care Kota Malang. E-Journal 3(1):200-208.

[APJII] Asosiasi Pengguna Jasa Internet Indonesia. 2020. Survei pengguna internet APJII 2019-Q2 2020: Ada kenaikan 25,5 juta pengguna internet baru di RI. https://apjii.or.id/downfile/file/ 
BULETINAPJIIEDISI74November2020.pdf. [22 Jan 2021].

Anthony BJ. 2021. Implications of telehealth and digital care solutions during COVID-19 pandemic: A qualitative literature review. Informatics for Health and Social Care 46(1):68-83. https://doi. org/10.1080/17538157.2020.1839467.

Hermes S, Riasanow T, Clemons EK et al. 2020. The digital transformation of the healthcare industry: exploring the rise of emerging platform ecosystems and their influence on the role of patients. Business Research 13:1033-1069. https://doi.org/10.1007/s40685-020-00125-x.

Kapoor A, Guha S, Das MK, Goswami KC, Yadav R. 2020. Digital healthcare: the only solution for better healthcare during COVID-19 pandemic? Indian Heart Jounal 72(2):61-64. https://doi. org/10.1016/j.ihj.2020.04.001.

Kurniasih D. 2013. Analisis Perancangan skateboard dengan quality function deployment-house of quality. Spektrum Industri 11(2):117-242. https://doi.org/10.12928/si.v11i2.1659.

Loomba A, Sandeep V, NavyaDeepthi D, M Shravani, Priyanka K, Mukesh T, and Anthony VD. 2019. Use of a tablet attachment in teleophthalmology for real-time video transmission from rural vision centers in a three-tier eye care network in India: EyeSmart Cyclops. International Journal of Telemedicine and Applications 2019:1-9.https:// doi.org/10.1155/2019/5683085.

Markplus I, Zap C. 2018. Zap beauty index Agusutus 2020. http://zapclinic.com/zapbeautyindex. [5 Feb 2021].

Okereafor K, Adebola O, Djehaiche R. 2020. Exploring the potentials of telemedicine and other noncontact electronic health technologies in controlling the spread of the Novel Coronavirus Disease (COVID-19). International Journal in IT and Engineering 8(4):1-13.
Purwati A, Astri, and Hanif. 2019. Analisa total service quality management terhadap kepuasan pelanggan Go-Jek. Hirarki: Jurnal Ilmiah Manajemen Dan Bisnis 1(2):24-33.https://doi. org/10.30606/hirarki.v1i2.191.

Rao SS, Loeb AE, Amin RM, Golladay GJ, Levin AS, ThakkarSC. 2020. Establishing telemedicinein an academic total joint arthroplasty practice: Needs and opportunities highlighted by the COVID19 pandemic. Arthroplasty Today 6(3):617-22. https://doi.org/10.1016/j.artd.2020.04.014.

Sirapanji S. 2014. Rancang bangun aplikasi sistem pakar untuk menangani masalah kecantikan pada wajah menggunakan metode decision tree. Jurnal Ultimatics 6(1):9-14. doi:10.31937/ ti.v6i1.326.https://doi.org/10.31937/ti.v6i1.326.

Song X, Liu X, Wang C. 2020. The role of telemedicine during the COVID-19 epidemic in Chinaexperience from Shandong province. Crit Care 24(1):178.https://doi.org/10.1186/s13054-02002884-9.

Statista Research Development. 2020. Beauty \& personal care report 2020. https://www.statista. com/outlook/70000000/120/beauty-personalcare/indonesia. [19 Jul 2020].

Sugiarti I. 2017. Aplikasi perawatan wajah berdasarkan jenis kulit wajah. Simki-Techsain 1(12):1-10.

Torous J, Myrick KJ, Rauseo-Ricupero N, Firth J. 2020. Digital mental health and COVID-19: using technology today to accelerate the curve on access and quality tomorrow. JMIR Mental Health 7(3):1-6. https://doi.org/10.2196/18848.

Wijaya T. 2018. Managemen Kualitas dan Jasa. Ed ke-2. Jakarta : Indeks Jakarta.

Vidal-Alaball J, Acosta-Roja R, Pastor N, Sanchez U, Morrison D, Narejos S, Salvador A. 2020. Telemedicine in the face of the COVID-19 pandemic. Atención Primaria 52(6):418-422. https://doi.org/10.1016/j.aprim.2020.04.003. 